\title{
Afforestation of heathlands and its influence on the land cover, accumulation of plant biomass and energy flow in the landscape: An example from Zaborski Landscape Park
}

\author{
"Andrzej Nienartowicz, "Anna Lewandowska-Czarnecka, "Enrique Ortega, "Miłosz Deptuła, \\ "Anna Filbrandt-Czaja, "Magdalena Kownacka
}

\begin{abstract}
"Nicolaus Copernicus University, Faculty of Biology and Environment Protection, Chair of Geobotany and Landscape Planning, Lwowska 1, 87-100 Toruń, Poland, e-mail: anienart@umk.pl

${ }^{* *}$ Food Engineering School, State University of Campinas, Campinas, SP, Brazil
\end{abstract}

\begin{abstract}
In the mid-19th century, the sheep industry played a considerable part in sheep breeding in Pomerania. Livestock grazing took place on extensive heathlands developed as a result of land deforestation performed in the 17th and 18th century, as well as during and after the Napoleonic wars. The sheep industry and the related textile craft developed until the 1890s when the Prussian government began the restoration of forests after the period of their excessive exploitation. The Prussian government policy contributed to the afforestation and the growing forest range through purchasing of landed estates, in particular the Polish ones, and creating forest divisions, followed by reconstruction of forests.

This paper presents the history of the Widno estate belonging to Mr. Konstanty Przytarski. The estate was located in the northern part of the present-day Zaborski Landscape Park, near the town of Brusy and Chojnice. In 1894, the estate was sold to the Prussian forest administration.

The paper presents changes in the land use and the forest above-ground biomass. Furthermore, changes in the structure of the energy flow network through the natural and production-cultural subsystems are presented. The network structure was analysed according to the methodology presented by H.T. Odum. Data contained in the sales contract of the Widno estate were used in the analysis, together with a forest inventory book of the Prussian Forest Inspectorate Zwangshoff and inventory books of the Polish Inspectorate Przymuszewo.

The study highlighted the increasing role of sheep breeding on small family farms established by employees of the forest division on the leased lands.

This form of activity refers to the economic traditions in the region of Zabory.
\end{abstract}

Key words: ecological history, forestry, heathlands, landscape structure, energy flow network, sheep-farming, forest-stand biomass, Pomerania.

\section{Introduction}

The structure of today's forests in Europe has been most strongly affected by two economic activities in the past, i.e. deforestation and planting of pine monocultures to restore forest after the clear cutting or as an afforestation method on soils temporarily used by agriculture. Apart from ag- ricultural fields, heathlands and meadows with the dominance of psammophilous grasslands were common types of ecosystems in the deforested areas of Central Europe. The last two types of ecosystems were usually used as infertile grazing lands for sheep.

Deforestation and reforestation of abandoned agricultural fields, and ecological effects of these treatments in 
different parts of ecosystems and landscapes have been presented in many publications, including monographs (e.g. Watkins, 1993; Salbitano, 1988; Kirkby \& Watkins, 2008; Heil et al., 2007; Wallace et al., 1992; Zerbe \& Brande, 2003).

The process of forest development after afforestation of heathlands was presented by i.a. Leuschner and Rode (1998). Changes in physical and chemical properties of soil and their impact on the process of forest growth have been often analysed. Afforestation of heathlands in northern Germany were studied by i.a. Rode (1999a, b) and von Oheimb et al. (2008). In addition to forest stands, some authors focused on the whole plant species composition as part of the forest ecosystem, e.g. Koerner et al. (1997), Flinn and Vellend (2005), and Amici et al. (2012). On the other hand, changes in the energy flow through the natural and production-cultural subsystems were not analysed.

In the 19th century, a large part of Pomerania (i.e. the region located in north-western Poland between the Oder River in the west, the Vistula River in the east and the Noteć River in the south, adjacent to the southern coast of the Baltic Sea) was covered with heaths. Changes in the range of forests in the entire region in the last millennium were presented by Ślaski (1951) who used the cartographic method, while the range of forests at the turn of the 18th and 19th century in the eastern part, referred to as Gdansk Pomerania - by Zaborski (1935). The formed author created a map based on the written historical sources, the latter - based on Schrötter-Engelhardt's maps from 1796-1802, under the regulation of Frederick II for the new territories incorporated into Prussia, including the areas seized by Prussia in the three Partitions of Poland. A small forest range presented on Schrötter-Engelhardt's map does not represent the maximum deforestation as further reduction in the forest area followed during the Napoleonic Wars and afterwards, i.e. when Prussia repaid the timber contribution to France and freed the landlords from banning the logging and timber sales to cover the war debts. As a result of the above political and economic processes, the deforestation was so significant that in some places the area was completely devoid of vegetation (Kozikowski, 1911). In deforested areas dominated by heaths and pioneer grasslands, the sheep keeping developed (Wachowiak, 1993). According to historical sources, the number of sheep in Pomerania in the mid-19th century was about 3.8 million (Wielopolski, 1959). Cloth manufacture developed in towns; it supplied materials for the Prussian army and for export to Russia.

In Gdańsk Pomerania, which at the end of the 18th century became part of the Prussian state, the Polish landed estates were often afforested. In view of the financial difficulties of the owners, the lands were sold to the Prussian forest administration which was referred to as a green expropriator of the revenue office. Such transactions resulted in the landscape transformation (from non-forest to woodlands) parallel to changes occurring in the land-use type from agriculture and farming to silviculture focused on the reconstruction of forests in the form of pine monocultures and fast timber production.

Changes in the structure and the use of landscape involved changes in the energy flow. These changes can be best expressed by comparing the structure of the energy flow network before and after the land-use change. According to Hirata and Ulanowicz (1984), the network is an universal language, through which the development of biological, ecological, economic, social and political systems can be expressed. The above-mentioned authors developed a method to assess the network structure based on the information theory, which allows for the structure complexity (including the number of compartments, connections between the compartments and the number of loops), as well as import, export and dissipation of energy through compartments.

The aim of this study was to present changes in the landscape structure and in the energy flow network structure, which took place on the territory of one of the landed estates owned by Konstanty Przytarski. The history of this estate is an example of changes typically occurring in Gdańsk Pomerania.

\section{Location}

The study covered an area of 612.01 ha, which until the 1890 s constituted the Widno land estate owned by Konstanty Przytarski. In 1894, the land was sold to the Prussian government and became part of the Forest Inspectorate Zwangshoff created in 1890.

Nowadays, the land is managed by the Polish Forest Inspectorate Przymuszewo, which is subordinate to the Regional Management of State Forests in Toruń.

The study are is located in the south of the Pomerania Province, north-west of the Brusy town (Fig. 1). The area represents a part of the Zabory Landscape Park. In 1996, the Tuchola Forest National Park (Bory Tucholskie) was created in the central part of the landscape park. Since 2 June 2010, the area is part of the "Tuchola Forest" Biosphere Reserve.

In the north and west, the study area borders on Lake Milachowo, through which the Zbrzyca River flows a tributary of the Brda River. In the western part, the study area covers the flat lake valley floor where the village of Widno is located. The valley is overgrown with meadows and pastures. In the direct vicinity of the lake, the land is boggy. A plantation of willow was created there at the beginning of the $20^{\text {th }}$ century.

The northern shore of the lake is very steep. The highest elevations are on the western side and they gradually 


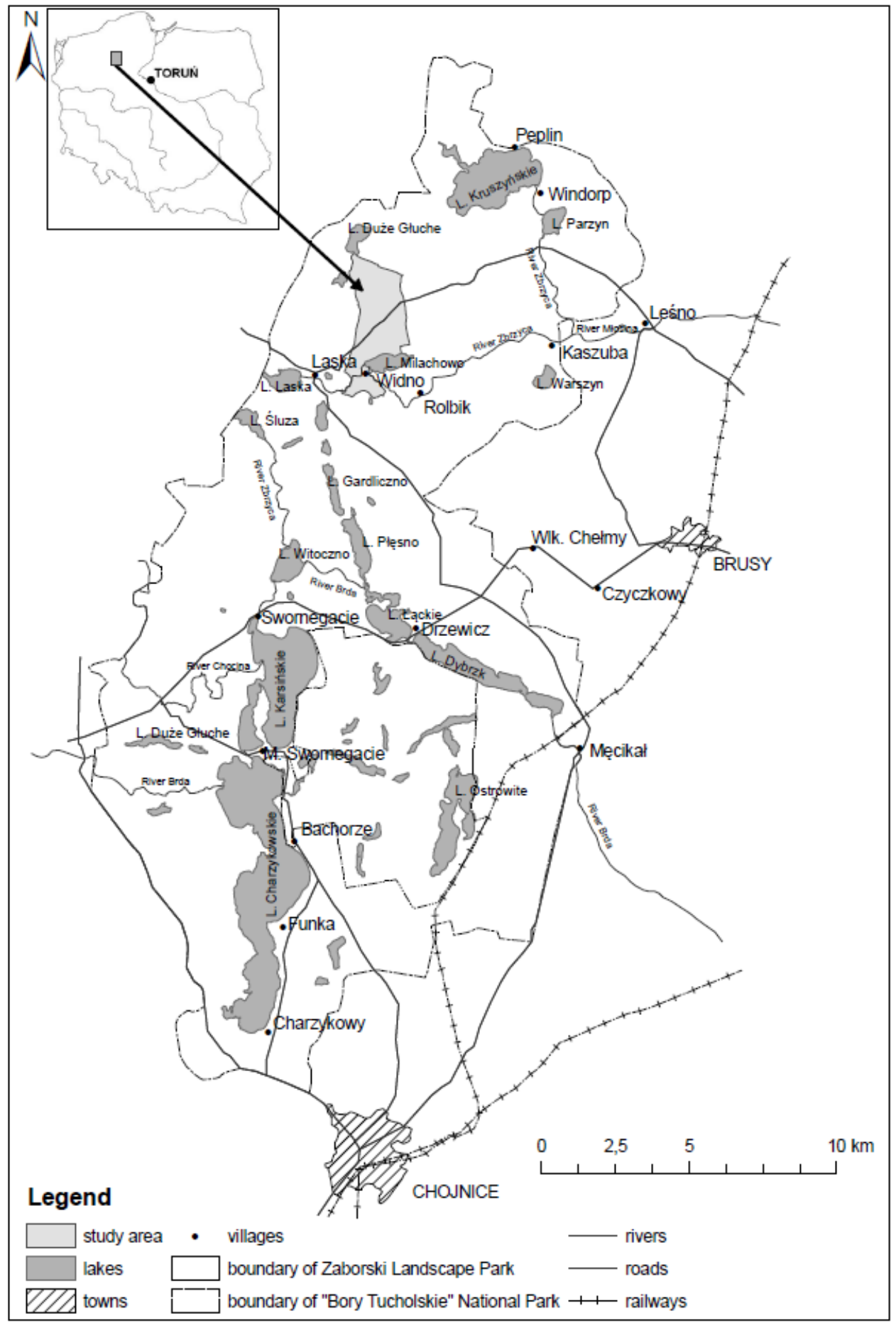

Figure 1. Location of the study area

diminish eastwards. The highest and the steepest shores of the lake are overgrown with oak-hornbeam deciduous forest with some Pinus strobus and Picea abies, (the association Galio-Carpinetum) and the higher places - with beech forest (the association Luzulo pilosae-Fagetum). The lower eastern shores are overgrown with Pinus sylvestris monocultures. The phytocoenoses are classified as fresh coniferous forest Leucobryo-Pinetum, dry coniferous forest Cladonio-Pinetum and heather-pine forests Pinus-Calluna (Nienartowicz et al. 1997/1998). In the central part of the 
northern shore of Lake Milachowo, the Orzechowo village (created by forest workers) is located, which encompasses small areas with buildings, backyards, meadows, gardens and crop fields of rye and potatoes.

Further north from the lake, there is a vast outwash plain overgrown with Scots pine plantations of varying age. Only small plantations of Pinus strobus and Pinus nigra have been created here. A deforested fire-protection belt runs through the northern part of the study area.

\section{Method}

Changes in the land use structure of the study area were described using the historical and contemporary cartographic materials. Other sources of information included the purchase-sale contract from 1894 for the land estate Widno and stock records of the forest administration from 1926, 1953, 1988 and 2009. The percentage area of each land-use form was read from the documents and maps after being analysed with the GIS technology, using the ESRI-ARC View software. Based on the thus obtained area, the ecological diversity of the study area was calculated, using the Shannon formula.

The calculations of the diversity index, as well as the evenness of land cover categories were conducted using the MVSP package (Kovach, 1986-2007).

Estimates were also made for the changes in the aboveground forest biomass occurring over the whole study area. The above-ground tree standing crop in $\mathrm{m}^{3}$ in 1926, 1953, 1988 and 2009 was obtained from the stock records contained in the forest inventory books. Details related to calculations are presented in the paper by Jarzębski et al. (2010).

Changes in the landscape exploitation were presented with the graphical method, in the form of diagrams prepared with the application of graphical symbols of "the energy language" introduced by Howard T. Odum (1971, 1988, 1996). Data on the subsequent land-use methods applied in the shepherding farm and everyday living come from the books written by Kukier (1968) and Cordes et al. (1997) as well as the article written by Christiansen (2001).

When drawing a network of flow through the 19th-century and contemporary landscape, the flow network models were used after Tilly (1999) for the past and present-day forestry sector in the USA, as well as the examples for small family farms provided by Cavalet et al. (2006), Franzeze et al. (2013) in Brazil, Rótolo et al. (2007) for cattle grazing on the Pampas in Argentina, as well as by Viglia et al. (2009-2011) for the agricultural sector in Cairngorms National Park and for whole Scotland, and by Haden (2003) for the entire agricultural sector in Denmark. Furthermore, the network structures from our previous studies conducted for the past and modern villages and landscapes in the Zaborski Landscape Park were used (Nienartowicz, 1996; Nienartowicz et al., 2008; Viglia et al., 2013). The program Visio was used to draw the network.

\section{Results}

\subsection{Changes in the land cover}

The analysis of the sale contract for the estate and the enclosed plan shows that in 1894 most of the study area was converted by sheep grazing (Fig. 2). The pastures with the dominance of heaths and a smaller contribution of xerothermic grasslands covered 476.36 ha, i.e. $77.84 \%$ of the total estate land. At that time, forest communities occurred only on the north-western shore of Lake Milachowo and over a small area north of the lake. The forest area in 1894 was 71.02 ha $(11.60 \%)$. Arable fields and gardens occupied 56.21 ha $(9.18 \%)$, meadows 7.29 ha $(1.19 \%)$, yards 0.76 ha $(0.13 \%)$ and buildings 0.37 ha $(0.06 \%)$.

Nowadays, most of the study area is covered by forests: 576.49 ha, i.e. $94.20 \%$ (Fig. 2). Mesophilous grasslands used as pastures cover only 7.68 ha, i.e. $1.25 \%$ of the land. Fields, meadows, yards and built-up areas occupy 12.83 , $2.65,1.67$ and 0.82 ha, i.e. $2.10,0.43,0.28$ and $13 \%$, respectively. About 9.87 ha (1.61\% of the land) is wasteland, mainly a swamp by the western shore of Lake Milachowo. The swamp was afforested with Salix sp. at the beginning of the $20^{\text {th }}$ century by Prussian foresters and added to the forest area, the total area of which increased to 586.36 ha and $95.81 \%$. Due to the dominance of one land-use form, viz. pastures, in 1894, and forests in 1997 (Fig. 3), the landscape heterogeneity in each of the two compared periods was low. The diversity index was 1.0462 in 1894 and only 0.3111 in 1997 . The evenness in those periods was much below 1 , viz. 0.4506 and 0.1340 , respectively. The comparison of the above values shows that the introduction of intensive forest culture caused a greater decrease in the landscape heterogeneity compared to crop cultivation and animal husbandry.

\subsection{Changes in the energy flow network}

The diagram of energy flow through the Widno estate from the end of the 19th century is a complex structure (Fig. 4). Nodes present in the flow graph are associated with plant production and crop harvesting. The heaths covered the largest area and provided fodder not only for animals but they were also a source of plant biomass, mainly thalli of lichens, used for field fertilization. Four nodes represent farm animals. Sheep play the most important role in the energy transfer. Other groups of animals in the system include cattle - oxen and cows as a source of milk, meat and the tractive force in the transport, crop cultivation and 

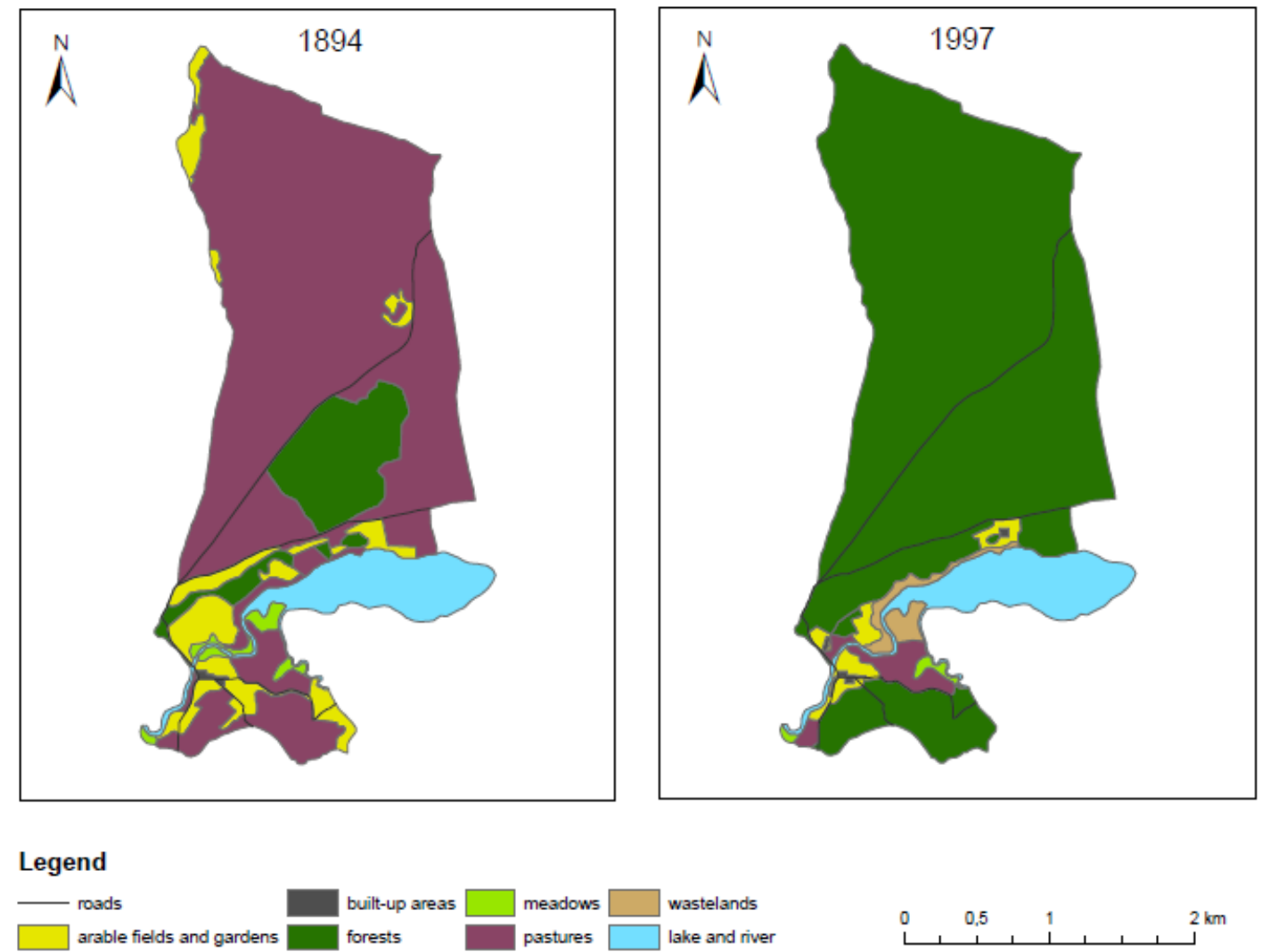

Figure 2. Map of the study area in 1894 and 1997
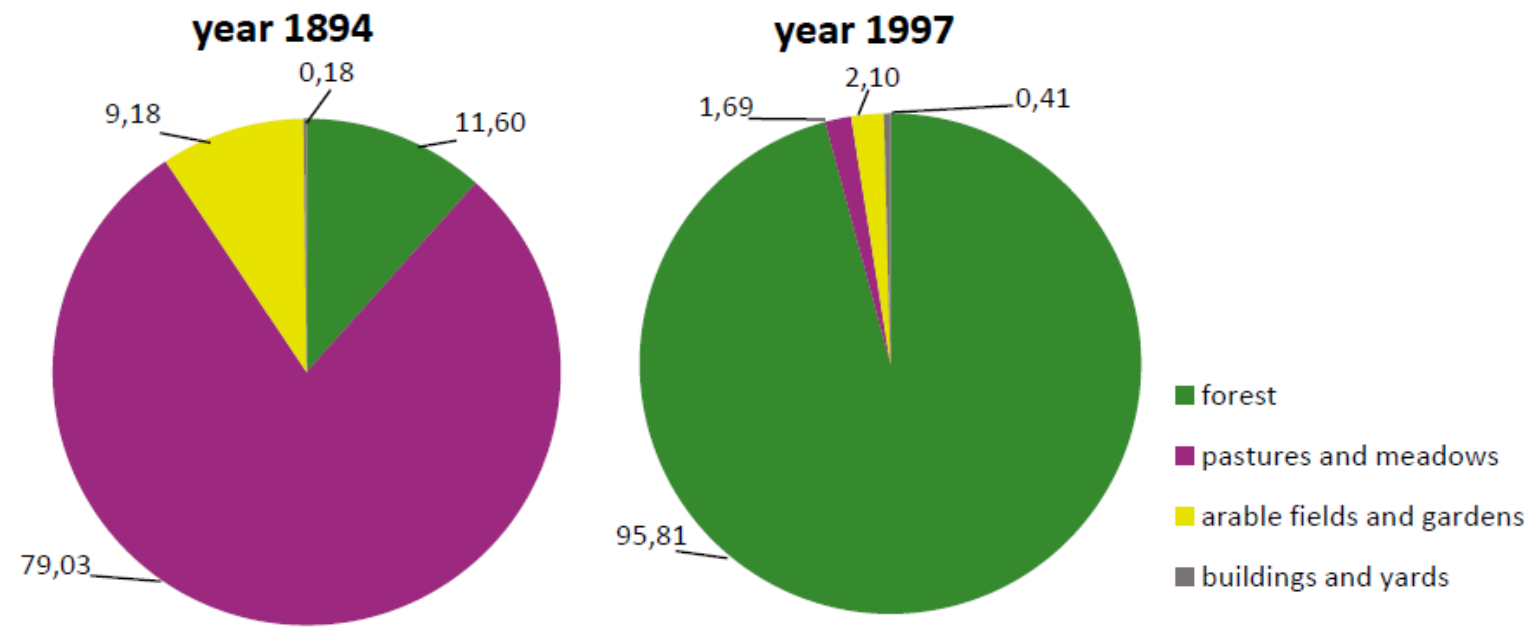

Figure 3. Changes in the land use/cover of the former estate land between 1894 and 1997 


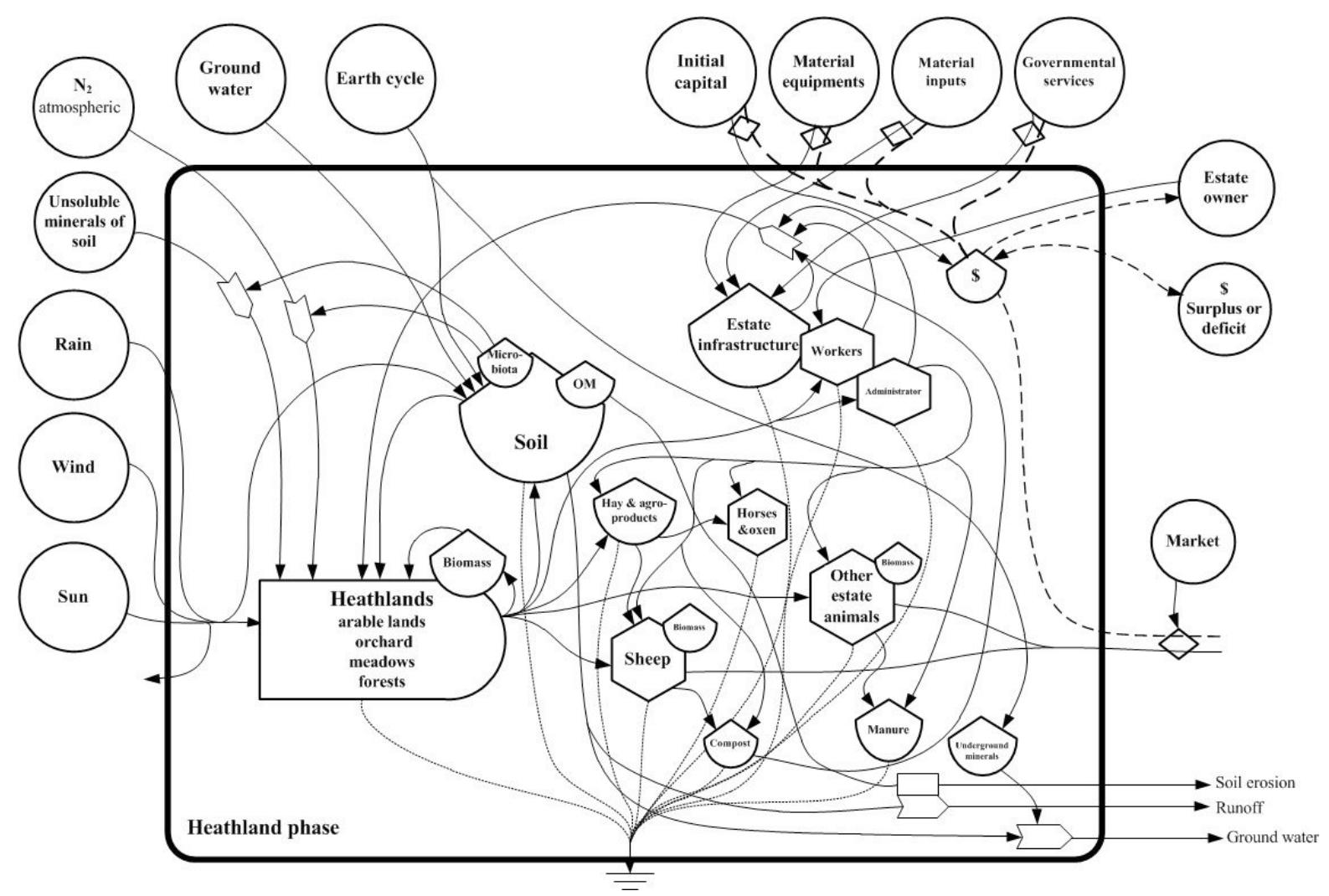

Figure 4. Emergy flow diagram in the Widno estate in 1894

crop harvesting. Furthermore, there are pigs and domestic fowl. The exchange of goods includes a delivery of crops to the market and purchasing new goods there. In addition to the purchased goods, the power supply of the system covers a supply of services, equipment and labour, e.g. the work of shepherds looking after the herd of sheep. The import and export of these various forms of energy is accompanied by the flow of capital, which is symbolized in the diagram by an arrow drawn as a dotted line. Due to a considerable deforestation of the area, the studied system was characterized by a large outflow of the rainwater and erosion. Both processes are represented in the graph by nodes at the bottom right corner of the diagram.

The afforestation of the land after 1894 significantly reduced the water runoff and erosion. After the estate was sold, forestry became the major economic sector in the study area. It is represented by two nodes in the flow graph - forest vegetation and processes of forest reconstruction and logging (Fig. 5). The subsystem of agricultural production and animal husbandry became dominated, miniaturized and reduced to a small area.

Almost all elements and processes occurring in the first phase of the development of the analysed area are represented by a large rectangle in the upper right corner of the second diagram. The subsystem of agricultural production and animal husbandry was limited to a small area of 23.92 ha $(3.91 \%)$, which is leased and used by employees of the forest division. Over the last 120 years, the area was used for plant and animal production. During that time, the contribution of sheep husbandry in the total animal production was decreasing. Breeding of pigs and cows was becoming increasingly important, followed by poultry keeping. The products were used by farmers, except for milk and eggs which were sold and exported outside the system. In the last few years, the importance of sheep keeping has been increasing again.

\section{Discussion and conclusions}

The analysis presented in this paper was based on qualitative data. At present, comparisons based on quantitative data are rather impossible, due to the fact that there are no historical data on the structure and functioning of the Widno estate. Only contemporary systems can be compared.

At present, two forester's lodges are located in the village of Widno. One of them together with the land used by a forester is located on the land that belonged to the former estate. The forester keeps sheep on the leased land. The main breeding herd consists of 20 sheep females, one ram 


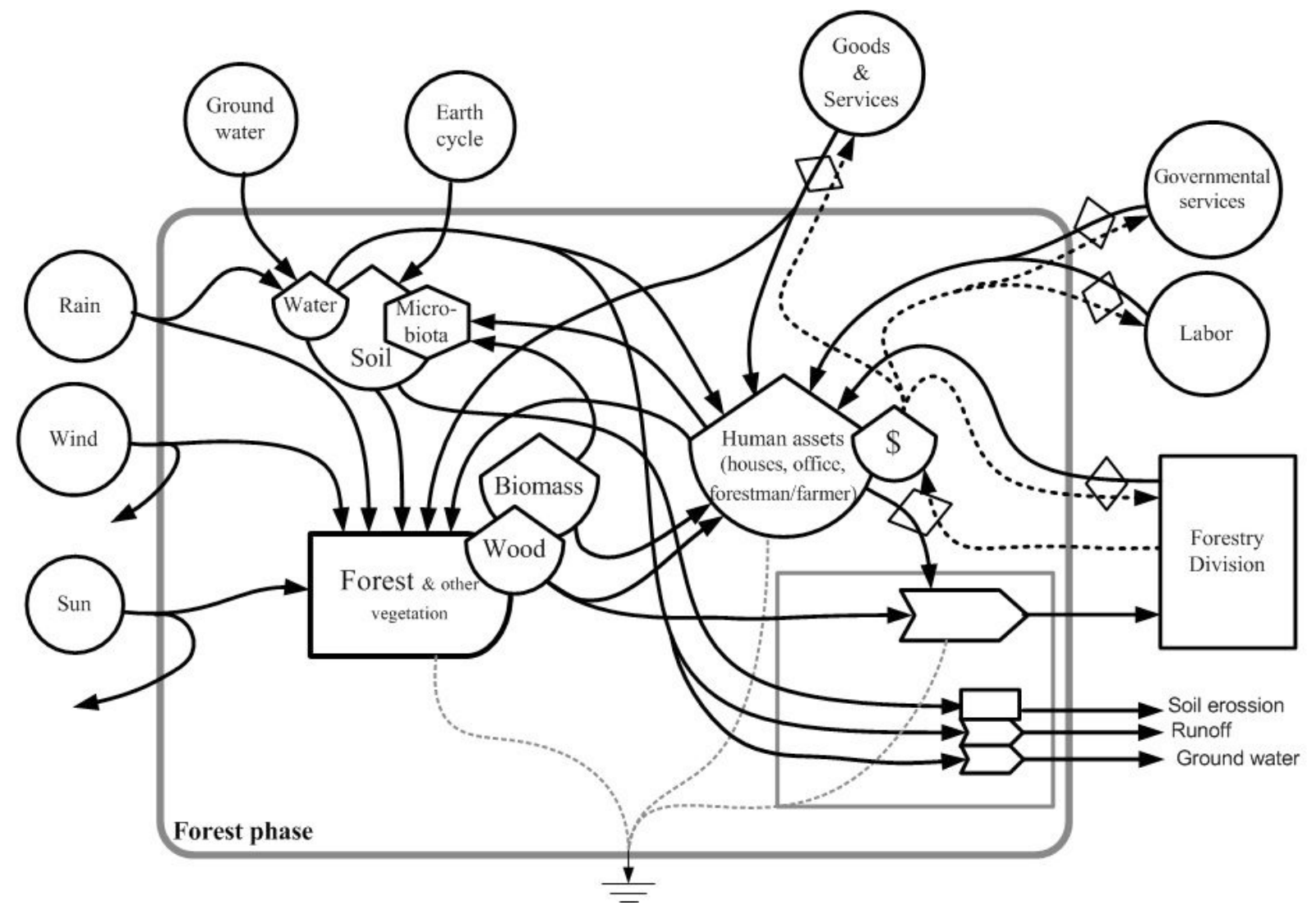

Figure 5. Emergy flow diagram in the Widno study area in 1997

and a few lambs. The land of this family farm is adjacent to another forester's lodge. In the past, the land leased by another forester was not located in the borders of the Widno estate. The other forester keeps and breeds sheep on a larger scale. His herd consists of 60 genetic sheep females, nine reserved sheep females, three rams and several lambs.

The breeding in both farms is based on grass pastures located at Lake Milachowo and along the Zbrzyca River. In the past, the lands located at higher altitudes were covered with heaths and then afforested. Small areas of heaths on the land division lines are included in the forest management program and livestock grazing is prohibited.

Two factors contributed to the growing role of the sheep husbandry in the recent period: 1) Small requirements of sheep in terms of feeding and rearing conditions. Sheep are satisfied with simple fodder and are comfortable on infertile grazing lands. They quickly become adapted to different climate and environmental conditions, and are characterized by high vitality and health. 2) Development of markets for products of animal husbandry in Poland and Pomerania.

Both of the today's sheep breeding farms in the village of Widno are good objects for the observations and comparisons in terms of energy analysis. Such comparisons can be conducted both in the units of direct energy, and in the units of embodied solar energy, i.e. energy according to the Odum's concept $(1971,1988,1996)$. In this case, the unit is referred to as sej (solar energy joule). Analysis of the flow and the balance expressed in the emergy units would allow the calculation of emergy sustainability indexes ESI for two compared modern sheep breeding farms according to the method proposed by Brown and Ulgiati (1997) and Brown and Ulgiati (1998). Perhaps the analysis of the historical material deposited in the Kashubian Museum in Wdzydze Kiszewskie and the Ethnographic Museum in Torun, related to ancient life styles of Pomerania's residents and their sheep breeding, will enable us to calculate ESI for the Widno estate from the latter half of the 19th century. Our further research will focus on the calculation of these indices.

\section{Acknowledgments}

The study was supported by the research fellowship under the Project "Enhancing Educational Potential of Nicolaus Copernicus University in the Disciplines of Mathematics and Natural Sciences" (project no. POKL.04.01.01-00081/10). 


\section{References}

Amici V., Rocchini D., Geri F., Bacaro G., Marcantonio M. \& Chiarucci A., 2012, Effects on an afforestation process on plant species richness: A retrogressive analysis, Ecological Complexity, 9: 55-62.

Brown M.T. \& Ulgiati, S., 1997, Emergy-based indices and ratios to evaluate sustainability: monitoring economies and technology toward environmentally sound innovation, Ecological Engineering, 9: 51-69.

Cavalett O., de Queiroz J.F. \& Ortega E., 2006, Emergy assessment of integrated production systems of grains, pig and fish in small farms in the South Brazil, Ecological Modelling, 193: 205-224.

Christiansen S., 2001, Flows of matter in a traditional heathland farm about 1840: An example from northern West Jutland, Denmark, Danish Journal of Geography, 101: 43-66.

Cordes H., Kaiser T., Lancken v. d. H., Lütkepohl M., \& Prüter J., 1997, Naturschutzgebiet Lüneburger Heide: Geschichte - Ökologie - Naturschutz, Verlag H. M. Hauschild GmbH, Bremen.

Flinn K.M. \& Vellend M., 2005, Recovery of forest plant communities in post-agricultural landscapes, Frontiers in Ecology and the Environment, 3: 243-250.

Franzese P.P., Cavalett O., Häyhä T. \& D’Angelo S., 2013, Integrated Environmental Assessment of Agricultural and Farming Production Systems in the Toledo River Basin (Brazil), UNESCO, International Hydrological Programme, Paris.

Haden A.C., 2003, Emergy Evaluations of Denmark and Danish Agriculture: Assessing the Limits of Agricultural Systems to Power Society, Ecological Agriculture 37, Centre for Sustainable Agriculture, Swedish University of Agricultural Sciences, Uppsala.

Heil G.W., Muys, B. \& Hansen, K. (eds), 2007, Environmental Effects of Afforestation in North-Western Europe: From field observation to Decision Support, Springer, Dordrecht, The Netherlands.

Hirata H. \& Ulanowicz R.E., 1984, Information theoretical analysis of ecological network, International Journal of Systems Science, 15: 261-270.

Jarzębski M., Nienartowicz A., Deptuła M., Bubnicki J. \& Domin D.J., 2010, Past, current and potential resources of carbon and above-ground plant biomass in the landscape with heats in Tuchola Forest, Ecological Questions, 13: 9-27.

Kirkby K. J. \& Watkins Ch, 2008, The Ecological History of European Forests, CABI Publishing, CPI Anthony Rowe, Eastbourne.

Koerner W., Dupouey J. L., Dambrine E. \& Benoit N., 1997, Influence of past land use on the vegetation and soils of present days forest in the Vosges mountains, France, Journal of Ecology, 85: 351-358.
Kovach W.L., 1986-2007, MVSP Plus version 3.1, Pentraeth, UK.

Kozikowski A., 1911, Historya lasów Prus Królewskich w świetle prawdy [History of forests in Royal Prussia in the light of truth], Sylwan, 29(8): 337-350 (in Polish).

Kukier R., 1968, Kaszubi bytowscy: Zarys monografii etnograficznej [Kashubians from the Bytów region: Outline of ethnographic monograph], Wydawnictwo Morskie, Gdynia.

Lauschner Ch. \& Rode M.W., 1999, The role of plant resources in forest succession: changes in radiation, water and nutrient fluxes, and plant productivity over a 300-yr-long chronosequence in NW-Germany, Perspectives in Plant Ecology, Evolution and Systematics, 2(1): 103-147.

Nienartowicz A., 1996, Energetyka dużych systemów ekologicznych [Energetics of large ecological systems], Wyd. UMK, Toruń.

Nienartowicz A., Filbrandt-Czaja A., Deptula M. \& Boinski M., 1997/1998, Changes in land use and their effect on species diversity and above-ground standing crop in the surroundings of lake Milachowo, [in:] S. Borsuk. (ed.), Research of the lakes in national parks and other protected areas, II Int. Scientific Conference, Wyd. Habitat, Bydgoszcz: 20-31.

Nienartowicz A., Deptuła M., Domin D. J., 2008, Zużycie energii kulturowej i wpływ działań człowieka na strukturę krajobrazu w kluczu zaborskim w XV-XVIII wieku [Cultural energy consumption and human influence on the structure of landscape in the Zabory Demesne in the 15th-18th c.], Kwartalnik Historii Kultury Materialnej, 3-4: 375-395.

Odum H.T., 1971, Environment, power and society, John Wiley, New York.

Odum H.T., 1988, Self organization, transformity and information, Science, 242: 1132-1139.

Odum H.T., 1996, Environmental accounting: Emergy and environmental decision making, John Wiley \& Sons, New York.

Rode M.W., 1999a, Influence of forest growth on former heathland on nutrient input and its consequences for nutrition and management of heath and forest, Forest Ecology and Management, 114: 31-43.

Rode M. W., 1999b, The interaction between organic layer and forest growth and forest development on former heathland, Forest Ecology and Management 114: 117-127.

Rótolo G.C., Rydberg T., Lieblein G. \& Francis C., 2007, Emergy evaluation of grazing cattle in Argentina's Pampas, Agriculture, Ecosystema and Environment, 119: 383-395. 
Salbitano F. (ed.), 1988, Human influence on Forest Ecosystem Development in Europe, Pitagora Editrice, Bologna.

Ślaski K., 1951, Zasięg lasów na Pomorzu w ostatnim tysiącleciu [The range of Pomeranian forests in the last millennium], Przegląd Zachodni VII, 1951(1-4): 207-263 (in Polish).

Tilley D. R., 1999, Emergy basis of forest systems, Ph. D. Thesis, University of Florida, Gainesville.

Ulgiati S. \& Brown M.T., 1998, Monitoring patterns of sustainability in natural and man-made ecosystems, Ecological Modelling, 108: 23-36.

Wachowiak B., 1993, Dział II: Gospodarka i społeczeństwo (wieś i miasto) [Section II: Economy and Society (the Countryside and the City)], [in:] G. Labuda (ed.), Historia Pomorza Vol. III (1815-1850), Część I Gospodarka, społeczeństwo, system polityczny [History of Pomerania], Vol. III (1815-1850), Part I Economy, Society, Political system], Pozn. Tow. Przyj. Nauk., Poznan: 177-321.

Wallace H.L., Good J.E.G. \& Williams T.G., 1992, The effects of afforestation on upland plant communities: an application of the National Vegetation Classification, Journal of Applied Ecology, 29: 180-194.

Watkins Ch., 1993, Ecological Effects of Afforestation: Studies in the history and ecology of afforestation in Western Europe, CABI International, Redwood Press, Melksham.

Wielopolski A., 1959, Gospodarka Pomorza Zachodniego w latach 1800-1918 [Economy of West Pomerania in 1800-1918], Societas Scientiarum Stetinensis, Faculty of Social Sciences, Vol. II, Szczecin (in Polish).
Viglia S., Franzese P.P., Zucaro A., Blackstock K.L., Matthews K.B. \& Ulgiati S., 2009-2011, Resource use and biophysical constraints of Scottish agriculture, [in:] S. Viglia (ed.), Evaluation of natural capital and ecosystem services: Assessing investments and benefits of environmental conservation options, International Doctoral Programme in Environment, Resources and Sustainable Development, XXIV cycle, Parthenope University, Naples: 66-85.

Viglia S., Nienartowicz A., Kunz M., Franzese P.P., 2013, Integrating Environmental Accounting, Life Cycle and Ecosystem Services Assessment, Journal of Environmental Accounting and Management, 1(4): 307-319.

von Oheimb G., Härdtle W., Naumann P.S., Westphal Ch., Assmann T. \& Meyer H., 2008, Long-term effects of historical heathland farming on soil properties of forest ecosystems, Forest Ecology and Management, 255: 1984-1993.

Zaborski B., 1935, Kaszuby na przełomie XVIII I XIX wieku w świetle mapy Schröttera-Engelhardta $\mathrm{z}$ lat 1796-1802 [Die Kaschubei am Anfang des XIX. Jahrhunderts im Lichte der Karte von Schrötter-Engelchardt A.D. 1796-1802], Wiadomości Służby Geograficznej, 18: 239-262.

Zerbe S. \& Brande A., 2003, Woodland degradation and regeneration in Central Europe during the last 1,000 years - a case study in NE Germany, Phytocoenologia, 33(4): 683-700. 